Hegel-Jahrbuch

2014 


\section{Hegel-Jahrbuch 2014}

Herausgegeben von

Andreas Arndt, Myriam Gerhard, Jure Zovko

Begründet von

Wilhelm Raimund Beyer ( $t$ ) 


\section{Hegel gegen Hegel I}

Herausgegeben von

Andreas Arndt, Myriam Gerhard, Jure Zovko

in Verbindung mit

Önay Sözer und Alper Turken

\section{DE GRUYTER}


ISSN 0073-1579

Library of Congress Cataloging-in-Publication Data

A CIP catalog record for this book has been applied for at the Library of Congress.

Bibliografische Information der Deutschen Nationalbibliothek

Die Deutsche Nationalbibliothek verzeichnet diese Publikation in der Deutschen Nationalbibliografie; detaillierte bibliografische Daten sind im Internet über http://dnb.dnb.de abrufbar.

(C) 2014 Walter de Gruyter GmbH, Berlin/München/Boston

Druck und Bindung: $\mathrm{CPI}$ books $\mathrm{GmbH}$, Leck

@ Gedruckt auf säurefreiem Papier

Printed in Germany

www.degruyter.com 